
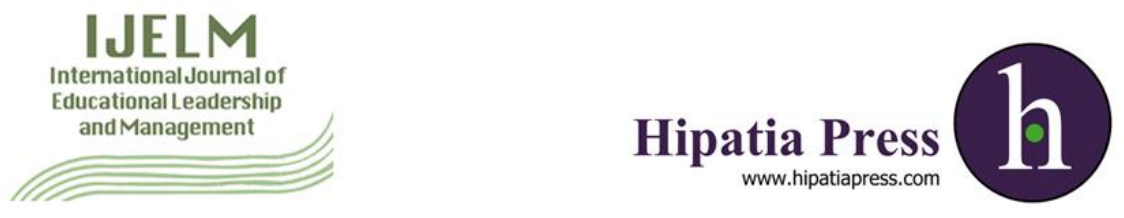

Instructions for authors, subscriptions and further details:

http://ijelm.hipatiapress.com

\title{
The Adaptation of Behavior and Instructional Management Scale into Turkish Language Context: Validity and Reliability Analysis
}

Ali Sabanci ${ }^{1}$ \& Gülnar Özyildirim ${ }^{1}$

1) Akdeniz University, Turkey.

Date of publication: January $16^{\text {th }}, 2020$

Edition period: July 2019 - January 2020

To cite this article: Sabanci, A. \& Özyildirim, G. (2020). The Adaptation of Behavior and Instructional Management Scale into Turkish Language Context: Validity and Reliability Analysis. International Journal of Educational Leadership and Management, 8(1), 34-59. doi: 10.17583/ijelm.2020.4825

To link this article: http://dx.doi.org/10.17583/ijelm.2020.4825

\section{PLEASE SCROLL DOWN FOR ARTICLE}

The terms and conditions of use are related to the Open Journal System and to Creative Commons Attribution License (CCAL). 


\section{The Adaptation of Behavior and Instructional Management Scale into Turkish Language Context: Validity and Reliability Analysis}

\author{
Ali Sabanci \\ Akdeniz University \\ Turkey
}

\author{
Gülnar Özyildirim \\ Akdeniz University \\ Turkey
}

\section{Abstract}

Teachers' adopted behaviors and their instructional management strategies are likely to have some differences on the basis of personal differences. This idea may be due to different beliefs about how effective education and teaching should be. The aim of this study is to adapt the Behavior and Instructional Management (BIM) Scale, which aims to measure teachers' beliefs about the management of their behavior and instruction, into Turkish language context and to conduct validity and reliability analysis. The population of the study consists of teachers working in state primary and secondary schools in Antalya, Turkey. The sample of the study consisted of 280 teachers who were working at 15 state primary schools and 20 state secondary schools. The sample was determined randomly by the cluster sampling. According to the results of the exploratory factor analysis, the short form of the Behavior and Instructional Management Scale has been found to be appropriate to the expected two-factor theoretical structure. The confirmatory factor analysis model-data fit values are $\mathrm{p}=0.065, \chi^{2} / \mathrm{sd}=1.311, \mathrm{RMSEA}=0.046, \mathrm{NFI}=0.94, \mathrm{NNFI}=0.97$, $\mathrm{CFI}=0.99$, GFI $=0.93$, AGFI $=0.89$. The reliability and validity results of short form of the scale indicated that it can be used in the future research on this topic.

Keywords: Classroom management, Behavior managment, Instructional management, Beliefs. 


\section{La adaptación de la escala de comportamiento y manejo instruccional al contexto del idioma turco: análisis de validez y confiabilidad}

\author{
Ali Sabanci \\ Akdeniz University \\ Turkey
}

\author{
Gülnar Özyildirim \\ Akdeniz University \\ Turkey
}

\section{Resumen}

Es probable que los comportamientos adoptados por los maestros y sus estrategias de manejo de la instrucción tengan algunas diferencias en función de las diferencias personales. Esta idea puede deberse a diferentes creencias sobre la eficacia de la educación y la enseñanza. El objetivo de este estudio es adaptar la escala de comportamiento y manejo instruccional, que tiene como objetivo medir las creencias de los maestros sobre el manejo de su comportamiento e instrucción, en el contexto del idioma turco y realizar análisis de validez y confiabilidad. La población del estudio consiste en maestros que trabajan en escuelas primarias y secundarias estatales en Antalya, Turquía. La muestra del estudio consistió en 280 maestros que trabajaban en 15 escuelas primarias estatales y 20 escuelas secundarias estatales. La muestra se determinó aleatoriamente por el muestreo por conglomerados. De acuerdo con los resultados del análisis factorial exploratorio, se ha encontrado que la forma abreviada de la Escala de Conducta y Manejo Instruccional es apropiada para la estructura teórica de dos factores esperada. Los valores de ajuste del modelo de análisis factorial confirmatorio son $\mathrm{p}=0.065, \chi 2 / \mathrm{sd}=1.311$, RMSEA $=0.046$, NFI $=0.94, \mathrm{NNFI}=0.97, \mathrm{CFI}=0.99, \mathrm{GFI}=0.93, \mathrm{AGFI}=0.89$. Los resultados de confiabilidad y validez de la forma abreviada de la escala indicaron que puede usarse en la investigación futura sobre este tema.

Palabras claves: Gestión del aula, gestión del comportamiento, gestión de la enseñanza, creencias. 
T he classroom is the smallest sub-system of the education system. Thus, it can be said that the starting point of effective and efficient maintaining it. It can be asserted that the management of behavior and instruction are two important factors for effective and efficient teaching in the classroom. Considering the effect of beliefs on behavior, it is believed that there is a need for a valid and reliable scale in this field, in Turkey. Therefore, the purpose of the study was to adapt "Behavior and Instructional Management" scale, which was developed by Martin and Sass (2010), into Turkish language context and to conduct validity and reliability analysis of it.

Teaching is a complex profession, because effective learning requires creating and maintaining classroom order along with many other issues during classroom activities (Laut, 1999; Rosas \& West, 2009). The most important factor in student learning is the teacher. Therefore, his/her ability to manage the class also affects the quality of teaching and student success (Igbinoba \& Marvelous, 2015; Marzano, Gaddy, Foseid, Foseid \& Marzona, 2005). While the interest in the instructional role of teachers is quite intense, less emphasis is placed on the knowledge and skills of teachers in management and discipline (Ming-tok \& Wai-shing, 2008). However, classroom management has always been an important issue for all education workers. Since behavior and classroom management takes a lot of time from teachers and school administrators and educators consider management ability as an indicator of teacher success (Laut, 1999; Shepherd \& Linn, 2015). One of the most important roles of the teachers in the classroom is that they are the managers of the class (Emmer, Evertson \& Worsham, 2006; Martin \& Shoho, 2000; Martin, Yin \& Mayall, 2006; Marzano, Marzano \& Pickering, 2003). Effective classroom management is a critical factor for providing a learning environment that promotes academic achievement as a measure of accountability (Rosas \& West, 2009). 


\section{Literature Review}

Classroom management encompasses all tasks involving a wide range of actions and attitudes related to teaching and learning that teachers and students perform on a given day. Educators discuss classroom management from different perspectives, but the core of these different perspectives be based on how the interaction among students, teachers and the content to be taught should be in an effective learning environment (Hall, Quinn \& Gollnick, 2017). According to Burden (2017), classroom management is the creation of a learning environment that will provide students with learning and positive social interactions. Also Martin, Yin and Baldwin (1997) defines classroom management as the teacher's effort in a wide range of areas to monitor learning, social interaction and student behavior in the classroom; most of the time it is often perceived only as discipline, but it is a very comprehensive concept, including discipline. In the light of all this information, classroom management can be defined as any action that the teacher makes in order to provide and maintain a compassionate and orderly environment that will enable students to learn both social and emotional development and academic learning (Evertson \& Weinstein, 2006).

The importance of classroom management makes it critical to determine how this process takes place (Evertson \& Weinstein, 2006). Many teachers are disillusioned when they try their ideas and strategies about classroom management in an inconsistent way and do not get what they want (Bosch, 2006). So, teachers should be clear about the classroom conditions and student behaviors needed for a healthy learning environment for providing effective classroom management (Emmer, Evertson \& Worsham, 2000) because one of the responsibilities of an effective class manager is to determine a philosophical point of view in class management and discipline (Burden, 2017). Teachers' beliefs and attitudes about the nature of student behavior and how to manage the classroom are influential on their behaviors (Laut, 1999; Willower, Eidell \& Hoy, 1967; Wolfgang \& Glickman, 1980). Their beliefs are reflected in their discipline, communication and instructional methods, and the physical management of the class (Gurcay, 2015; Martin et al, 2006; Martin, Yin \& Baldwin, 1998). 
Glickman and Tamashiro (1980), Wolfgang and Glickman (1980) and Wolfgang and Wolfgang (1995) made a belief classification based on a school of thought about how the students learn, develop and grow. According to this school of thought, in general, they tend to be either interventionist, interactionist or non- interventionist though teachers use different methods in all approaches at times. It is stated that the differences in teacher's beliefs derives from their perception on nature of desired and undesired behaviors and their style of behavior management (Martin \& Baldwin, 1992) and the understandings of teachers on how they should communicate with children (Tauber, 2007). In addition, Glickman and Tamashiro (1980) argue that these approaches were based on the sharing of control in the classroom management process between teacher and student. In other words, the three techniques used in any case were based on the specific power relationship between the teacher and the student. In some techniques, the student is provided an opportunity to correct his behavior, while in other teachers possess entirely all control power (Onwuegbuzie, Witcher, Filer \& Downing, 2000).

The non-interventionist approach is based on that children have inner power that they need to find meaning in the real world (Martin, Yin \& Mayall, 2007) and it argues that they have inherent competence in solving his problems. The approach points out that when the necessary support and opportunity is provided, children will reach the level of consciousness at which they can correct their own undesired behaviors. In this approach, the teacher does not apply his / her own rules on the students. The control is largely on the students (Glickman \& Tamashiro, 1980). Tauber (2007) embodied this approach with flower care. If the children are not controlled and only fed on water, soil and sunlight, they will bloom. The child development doesn't depend on the teacher controlling. Students also have a natural desire to learn. Glickman and Tamashiro (1980) stated that undesired behaviors were the results of unresolved intrinsic conflicts. The teacher who uses this approach supports the students with visual cues and non-guiding expressions for self-correction. The techniques of this approach are empathetic towards the students and directing, reflective questions to them (Onwuegbuzie et al., 2000). 
The interventionist approach is based on the idea that environmental conditions are effective in the child development. It is necessary that the teacher with this belief is to control the environment. For this teacher, changing the student behavior is both a correct behavior and a necessity (Tauber, 2007). Students learn only the reinforced behaviors and their undesired behaviors derive from the inadequacy of the reward and punishment given to them (Glickman \& Tamashiro, 1980).

The mid-point of these two approaches is the interactionist approach. If there is a problem in the interactionist approach, the solution to this problem should be shared with all parties in the decision process just like a twoperson tango (Tauber, 2007). The rules that satisfy all parties are complied with. Control is shared equally between the teacher and students (Glickman \& Tamashiro, 1980). In the interactionist approach, both interventionist and non-interventionist techniques are used together. Teachers who adopt this approach sometimes lead to nondirective questions, and sometimes use directive statements (Onwuegbuzie et al., 2000).

Research over the last thirty years has indicated that classroom management is a critical factor both for effective teaching (Marzano et al., 2003) and for teachers' early quitting (Gonzalez, Brown \& Slate, 2008; Rosas \& West, 2009). Each teacher desires to teach effectively and to occur meaningful learning in students. The most important point is that the teachers do not reach their goals because of the academic and behavioral problems of students they are responsible for (Gonzalez et al., 2008; Mingtok \& Wai-shing, 2008; Rosas \& West, 2009; Rust, 1992; Williams, 2009). Understanding the place of a disciplinary approach in a broad sense will enable the teachers to choose an approach and to defend their preferred approach. In this case, they will know why the other approach should not choose and will be more accountable. In addition, the discipline approach, which is the reflection of one's philosophy, provides guidance for them in decision-making in cases related to classroom management (Tauber, 2007). 
When teachers begin to understand classroom discipline models which encourage students to discipline themselves, and implement these models, they will help both being internalized the desired behaviors in the classroom by the students and guiding the students outside the classroom (Charles, 1991). Moreover, Doyle (1986) states that classroom management strategies are important in establishing and maintaining a healthy classroom climate for effective teaching. These strategies have a philosophical and applied or theoretical basis (Akbaba \& Altun, 1998). The theoretical approaches of classroom management are important because they provide a foundation for analyzing and understanding teacher and student behavior (Levin \& Nolan 1991). Furthermore, research on aspects of classroom management will provide a clearer understanding of this issue and it will contribute to the educational process for prospective teachers at the undergraduate level, and in-service teachers at the graduate level and in-service training (Martin, et al., 1997). In addition, researchers find it useful to investigate teachers' beliefs about the management of behavior and instruction from different ethnic and cultural backgrounds. Therefore, it is expected to meet a need for research to be conducted in Turkey through this instrument. It is wise to assert that adaptation of a tool with validity and reliability studies in various countries in terms of factor structure and psychometric characteristics will contribute more to the field rather than developing a new instrument. Martin and Sass (2010) stated that confirmation of model of this tool they developed into different cultures contribute to the international validity of the tool.

\section{Methodology}

In this part of the study, the detailed information on the aim of the study, the adaptation process, population and sample, Behavior and Instructional Management Scale and research ethics was presented respectively. 


\section{Aim of the study}

In the study, firstly, the 24-item long form of the "Behavior and Instructional Management Scale" and the 12-item short form of the scale were adapted to Turkish and then validity and reliability studies were conducted. In order to provide language validity, seven experts including the researchers, took charge in. Expert opinion was taken for face validity, and structural validity was provided using exploratory and conformity factor analysis. For reliability of the scale, Cronbach's alfa coefficient was calculated using.

The Behavior and Instructional Management Scale has been used to determine teachers' beliefs about the management of behavior and instruction in various studies and in different countries (Jalali, Panahzade \& Firouzmand, 2014; Martin et al., 2012; Sass, 2011; Unal \& Unal, 2012; Sass, Lopes, Oliveira \& Martin, 2016). Without stating which forms of BIM (long or short form of it), Unal and Unal (2012) also adapted the scale to Turkish by using inter-linguistic equivalence, inter-cultural conceptual equivalence and normative equivalence. Reliability of the scale was analyzed, but for validity of the scale, no study was conducted. In this study, validity and reliability studies for long and short form of the Behavior and Instructional Management Scale were conducted integrally using scale adaptation steps, which were reported in detail below.

\section{The adaptation process}

In the process of adaptation of the "Behavior and Instructional Management (BIM) Scale" the steps specified by Hambleton and Patsula (1999), and the form of scale adaptation steps and principles prepared by Cum and Koc (2013) were referred to. The adaptation process was performed in nine steps. Firstly, during adaptation, researchers examined the theoretical and practical aspects of teacher beliefs on behavior and instructional management and decided that this scale could measure the targeted structure for the research conducted in Turkey. Secondly, it was 
thought that adaptation of an existing scale related to this issue would benefit both in comparing the results of researches to be made among cultures and to contribute to international validity studies. Thirdly, permission was obtained from the researchers who developed the scale through e-mail for the adaptation of the scale to Turkish. Fourth, six people who have teaching experience and are experts on both of the languages took part in the translation of the scale into Turkish. Fifth, the researchers of this study selected the best of translated items together with an associate professor who is an expert in both languages and has teaching experience and they designed the Turkish version of the scale. Sixth, one expert in the assessment and evaluation department reviewed the scale in terms of face validity. Seventh, translated form of the scale and its original form were applied to 11 English teachers at three days intervals in terms of both performing pilot practice and determining the linguistic equivalence between its original form and target form. With the opinions obtained, the tool was reviewed for the last time and the linguistic equivalence was evaluated with the correlation between the dimensions. Eighth, the final version of the scale was applied to a small group from the target sample for exploratory factor analysis. Finally, validity and reliability analysis of the obtained model from confirmatory factor analysis were conducted through the data collected from the target sample.

\section{Population and sample}

The population of the study consisted of teachers working in 154 state primary schools and 204 state secondary schools in five central districts of Antalya province in Turkey. The sample was determined by cluster sampling method out of the population. The cluster method is one of the probabilistic sampling methods, in which the population is divided into groups and random participants are determined from these groups (Edmonds \& Kennedy, 2017).

For the exploratory factor analysis, the questionnaire was delivered to 200 teachers randomly selected from 15 primary schools and 20 secondary schools determined by the cluster sampling method and 120 questionnaires were gathered. Later, for the confirmatory factor analysis, 250 teachers, who 
had not received a questionnaire form from the same schools, were delivered questionnaires and 160 out of them were taken back. In scale adaptation studies, the size of the sample group is important (Secer, 2015). For a valid and reliable analysis, there is a general consensus to collect data 5 or 10 times higher than the number of items among the participants (Kass \& Tisley, 1979).

\section{Behavior and Instructional Management Scale}

Martin and Baldwin (1992) stated that there was a need for developing a new scale in order to determine beliefs of teachers on classroom management because the scales "Pupil Control Ideology" developed by Willower et al., (1967) and "Beliefs on Discipline Inventory" developed by Wolfgang and Glickman (1980) contextualized classroom management as classroom discipline. However, they thought that classroom management was a comprehensive term which didn't comprise only discipline and it included management of people, behavior and instruction. These researchers developed The Inventory of Classroom Management Style (ICMS). This tool was based on the belief classifications of Wolfgang and Glickman (1980) on child development, which were non-interventionist approach, interventionist approach and interactionist approach. It consisted of 10 items in three dimensions: discipline, instructional and people. The lowest score that can be obtained from this tool (10) represented non-interventionist approach, the highest score (30) represented the interventionist approach and the midpoint (20 points) represented the interactionist approach. Martin and Yin (1997) developed a new tool called "Attitudes and Beliefs on Classroom Control Inventory (ABCC)" by revising ICMS. This scale consisted of 26 items, including four dimensions, which were management of instruction (14 items), behavior management (4 items) and people management (8 items), and it was 4-point Likert type. The validity and reliability analyzes of this tool was conducted by Henson and Roberts (2001) and it was adapted to Turkish by Savran (2002). In both of the researches two-factorial structures were reported. Most of the items of behavior management dimension at ABCC were found to be in the dimension of people management, and then Martin et al., (2007), Henson and Roberts (2001) and Savran (2002) reported 
that it was appropriate to be described the two-factor structure as instructional and people management. Martin and Sass (2010) stated that there was no study on the psychometric properties of ABCC and that there were some problems in its factor structure, although the reliability and validity of $\mathrm{ABCC}$ has been re-examined many times. So, they developed a 6point Likert-type tool with both long and short forms called Behavior and Instructional Management Scale (BIM). BIM had 24 items (behavior management 12 items, instructional management 12 items) in long form, and 12 items (behavior management 6 items; management 6 items) in short form. As a result of the studies on the validity and reliability of this scale, it was stated that its short form could be used in research. In addition, its psychometric properties were found to be appropriate in comparison with "Ohio Teacher Efficacy Scale".

\section{Research Ethics}

Necessary permission was obtained from the researchers who developed the scale before starting the adaptation process of BIM. During the translation process of the scale, it was ensured that the experts were unaware of each other in order to prevent them from being affected. In addition, necessary permissions were obtained in the process of applying the questionnaire form consisting of BIM to both small and large groups, and the participants were voluntary in their participation in the research. There are no questions to reveal the identities of the participants in the questionnaire form.

\section{Results}

In this part of the study, language validity and construct validity studies and reliability analysis were conducted within the scope of the validity analysis of the Behavior and Instructional Management Scale. 


\section{Language Validation}

In order to ensure the language validity, highly qualified six experts in both English and Turkish languages were included in the translation process. Five of them graduated from the Department of English Language Education, and one of them graduated from the Department of English Linguistics.

In addition, two of the specialists in this group had $\mathrm{PhD}$ diploma and three of them had master's degree in Educational Administration and Supervision. One expert out of the same six experts had a master's degree in English Language Education. All the experts had teaching experience for several years. Three groups were organized in pairs. First of all, one person from each group independently translated the scale items from English to Turkish. Secondly, the other member of the pair conducted the back translation. So, the three groups produced three versions of the scale. Thirdly, apart from the translation group, researchers reviewed the items of these three versions and selected best of them together with one associate professor who was expert both in the field of educational administration and supervision and in Turkish and English languages. Fourthly, an expert from measurement and evaluation department reviewed the translated form of the BIM in terms of face validity. Finally, the researchers decided on the final form.

In order to ensure the structural equality of the scale both culturally and linguistically, 11 English teachers were asked to answer the Turkish and English versions of the scale at three days intervals. The Spearman correlation coefficient of the obtained data was calculated and presented in Table 1 and Table 2. 
Table 1.

Correlation of the scale's English and Turkish form for the behavior management dimension

\begin{tabular}{lll}
\hline & English form of the scale & Turkish form of the scale \\
\hline English form of the scale & 1 & $771^{*}$ \\
Turkish form of the scale & $771^{*}$ & 1 \\
\hline p $\leq 0.05$ & &
\end{tabular}

As given in table 1, the scores obtained from the English and Turkish form in the behavior management dimension of the scale were significantly correlated with each other $(r=.771, \mathrm{p} \leq 0.05)$.

Table 2.

Correlation of the scale's English and Turkish form for the instructional management dimension

$$
\text { English form of the scale Turkish form of the scale }
$$

\begin{tabular}{lll}
\hline English form of the scale 1 & $908 * *$
\end{tabular}

Turkish form of the scale $908 * * \quad 1$

$* * \mathrm{p} \leq 0.01$

As given in table 2, the scores obtained from the English and Turkish forms in the dimension of the management of the scale were significantly related to each other $(\mathrm{r}=.908, \mathrm{p} \leq 0.01)$.

Considering the expert opinions and correlation coefficients, it was accepted that the Turkish version of the scale was provided in its original state. 


\section{Construct validation}

In order to maintain the construct validity of the scale, exploratory factor analysis was conducted the data gathered with "Behavior and Instructional Management Scale" from a sufficient number of the target population.

In scale development and adaptation studies, factor analysis method is available to test construct validity (Buyukozturk, 2013; Secer, 2015). Exploratory factor analysis decreases the number of variables in the scale and allows the comparison of the structure obtained with the theoretical structure (Hair, Anderson, Tatham \& Black, 1998; Secer, 2015). First of all in order to test the suitability of the sample size the Kaiser-Meyer-Olkin value was calculated The Kaiser-Meyer-Olkin value was found to be (0.808) and according to this result the sample size is relevant for further analysis (Hutcheson \& Sofroniou, 1999). The significance of Bartlett's Test of Sphericity indicates the suitability of the relationships between variables for analysis and it was found as $(795.996)(p \leq 0.00)$ which is significant. In the analysis, principal component analysis and Varimax rotation technique were used.

In order to determine the factorial structures of the scale, the factors with 1 or higher eigenvalues and that variance explained was $2 / 3$ of the total variance were taken into consideration. Moreover, the factor loadings were to be higher than 0.40 (Buyukozturk, 2013). As a result of the first analysis, 5 factors with eigenvalues greater than 1 were found. 4 items (Items 3-4-1619) were removed from the scale due to the fact that they were referred to as overlapping items. The researchers decided to remove one item (Item 8) because it pretended a factor alone and one item (Item 9), because it was in a factor which was not correlated theoretically. The analysis was completed with 4 factors and 18 items. 
Table 3.

Factor eigenvalues of the long form of the scale and explained variance

\begin{tabular}{llll}
\hline & Eigenvalue & $\begin{array}{l}\text { Total variance } \\
\text { Explained }\end{array}$ & Cumulative variance \\
\hline 1 & 4.759 & 19.665 & 19.665 \\
2 & 3.363 & 18.130 & 37.795 \\
3 & 1.467 & 11.831 & 49.625 \\
4 & 1.001 & 9.2110 & 58.836 \\
\hline
\end{tabular}

As given in table 3, there were four factors whose eigenvalues were greater than 1 . The eigenvalues of these factors were $4.75 ; 3: 36 ; 1.467$ and 1 . The rate of variance explained by the four factors was $58.836 \%$. The variance rates explained by the factors were $19.66 \% ; 18.13 \% ; 11.83 \%$ and $9.21 \%$.

Table 4.

Factor loadings of the items in the long form of the scale

\begin{tabular}{|c|c|c|c|c|c|c|c|c|c|}
\hline 䔍 & 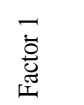 & 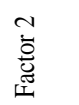 & 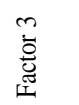 & 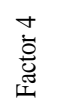 & 䔍 & 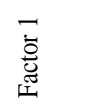 & 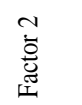 & 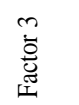 & 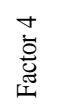 \\
\hline $\mathrm{i} 2$ & 0,768 & & & & i2 & & & 0.729 & \\
\hline i18 & 0.748 & & & & i20 & 0.404 & & 0.678 & \\
\hline i10 & 0.732 & & & & i22 & & 0.302 & 0.638 & \\
\hline i12 & 0.686 & & & & i7 & & & & 0.701 \\
\hline i6 & 0.680 & & & & i15 & & 0.386 & & 0.648 \\
\hline i14 & 0.622 & & & & i5 & -0.432 & & & 0.615 \\
\hline i17 & & 0.760 & & & & & & & \\
\hline i13 & & 0.741 & & & & & & & \\
\hline i1 & & 0.722 & & & & & & & \\
\hline i11 & & 0.665 & & & & & & & \\
\hline i23 & & 0.619 & 0.351 & 0.378 & & & & & \\
\hline i21 & & 0.616 & & & & & & & \\
\hline
\end{tabular}


As given in table 3, there were 6 items (items 2-18-10-12-6 and 14) in the first factor. The second factor included 6 items (items 17-13-1-11-21 and 23), the third factor had 3 items (items 2-20 and 22) and the fourth factor contained 3 items (items 7-15 and 5).

The exploratory factor analysis was conducted for the short form of the scale since the long form could not reach the 2-factor structure by means of exploratory factor analysis. The principal component analysis and Varimax rotation technique were used. The Kaiser-Meyer-Olkin value was found to be 0.788 , indicating that the sample size was good (Hutcheson \& Sofroniou, 1999). The significant value $(\mathrm{p} \leq 0.00)$ of Bartlett's Test of Sphericity (494.925) indicated that the relationships between variables were appropriate for analysis. In the continuation of the analysis, principal component analysis and Varimax rotation technique were used. Factor loadings of the items related to the short form of the scale were presented in Table 5.

Table 5.

Factor loadings of items in the short form of the scale

\begin{tabular}{lll}
\hline Items & Factor 1 & Factor 2 \\
\hline i24 & 0.823 & \\
i18 & 0.736 & \\
i10 & 0.729 & \\
i6 & 0.669 & \\
i12 & 0.654 & \\
i4 & 0.563 & \\
i17 & & 0.814 \\
i23 & & 0.799 \\
i21 & & 0.764 \\
i1 & & 0.667 \\
i15 & & 0.660 \\
i3 & & 0.578 \\
\hline Total Variance & $27.09 \%$ & $26.67 \%$ \\
\cline { 2 - 3 } & Total Variance Explained: 53.77\% & \\
\hline
\end{tabular}


In Table 5, there were two factors whose eigenvalues were greater than 1 . The eigenvalues of these two factors were 3.45 and 2.99 , respectively. The total variance explained rate was $53.77 \%$. The variance explained of the factors is $27.09 \%$ and $26.67 \%$ respectively.

According to the results, 6 items remained in the scale (Items 24-18-106-12-4) at the first factor and 6 items (Items17-23-21-1-15-3) at the second factor. No overlapping items were found and all of them were distributed to theoretically expected factors. In accordance with the original scale, first factor was named as instructional management and the second factor was named as behavior management.

Finally, confirmatory factor analysis was performed to confirm the twofactor structure consisting of 12 items obtained from exploratory factor analysis. Figure 1 illustrates the image of the confirmatory factor analysis model.

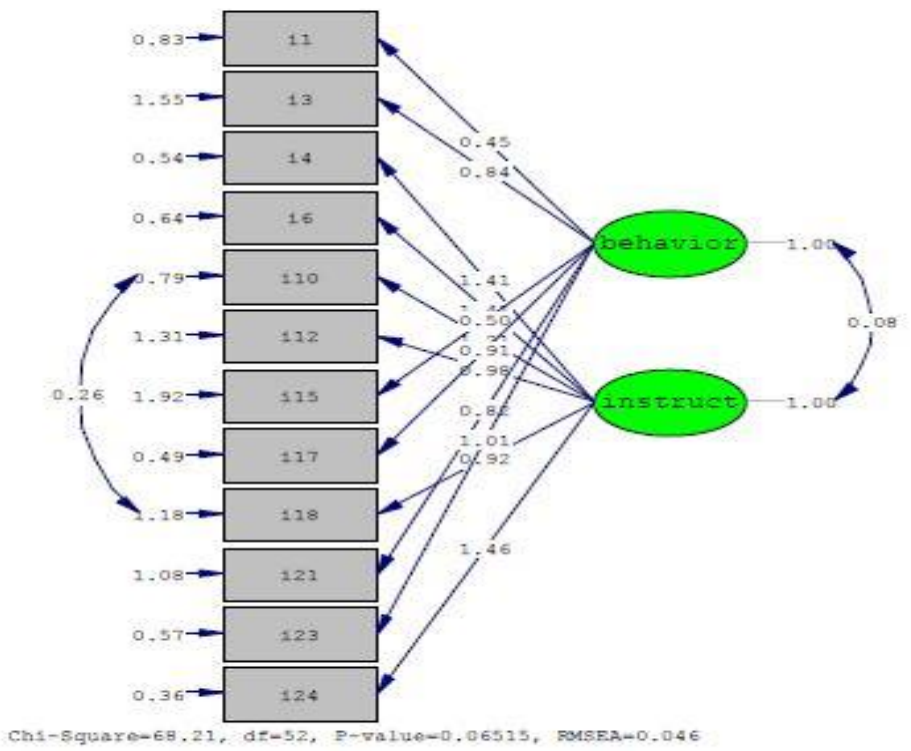

Figure 1. Conformity factor analysis model of the short form of the scale 
After an error covariance was conducted between items 10 and 18, t values of the observed variables ranged from 5.18 to 14.53 in the model obtained through conformity factor analysis. Moreover, it was observed that and the highest error variance of the observed variables was 0.88 while their lowest error variance was 0.15 . Their factor loadings ranged from 0.34 to 0.92. According to Cokluk, Sekercioglu and Buyukozturk (2012) t values of the items are to be higher than 2.56 for $\mathrm{p}<.001$ and error variances of the of the observed variables are to lower than 1.00 as well as factor loadings of the items are to be higher than 0.30 for a good model.

The statistics calculated by confirmatory factor analysis and values of model-fit are shown table 6 .

Table 6.

The statistics calculated by confirmatory factor analysis and values of model-fit

\begin{tabular}{|c|c|c|c|}
\hline & Goodness-of-Fit & Acceptable fit & The value of model \\
\hline$\chi^{2}$ & $0 \leq \chi 2 \leq 2 \mathrm{sd}$ & $2 \mathrm{sd} \leq \chi^{2} \leq 3 \mathrm{sd}$ & $1.311 \mathrm{sd}$ \\
\hline $\mathrm{p}$ & $0.05 \leq \mathrm{p} \leq 1.00$ & $0.01 \leq \mathrm{p} \leq 0.05$ & 0.065 \\
\hline$\chi^{2 / \mathrm{sd}}$ & $0 \leq \chi 2 / \mathrm{sd} \leq 2 \mathrm{sd}$ & $2 \leq \chi^{2 /} / \mathrm{sd} \leq 3$ & 1.311 \\
\hline RMSEA & $0 \leq \mathrm{RMSEA} \leq 0.05$ & $0.05 \leq$ RMSEA $\leq 0.08$ & 0.046 \\
\hline NFI & $0.95 \leq \mathrm{NFI} \leq 1.00$ & $0.90 \leq \mathrm{NFI} \leq 0.95$ & 0.94 \\
\hline NNFI & $0.97 \leq \mathrm{NNFI} \leq 1.00$ & $0.95 \leq \mathrm{NNFI} \leq 0.97$ & 0.97 \\
\hline CFI & $0.97 \leq \mathrm{CFI} \leq 1.00$ & $0.95 \leq \mathrm{CFI} \leq 0.97$ & 0.99 \\
\hline GFI & $0.95 \leq \mathrm{GFI} \leq 1.00$ & $0.90 \leq \mathrm{GFI} \leq 0.95$ & 0.93 \\
\hline AGFI & $0.90 \leq \mathrm{AGFI} \leq 1.00$ & $0.85 \leq \mathrm{AGFI} \leq 0.90$ & 0.89 \\
\hline
\end{tabular}

(Retrived from Hair et al., 1998; Jöreskog ve Sorbom, 1993).

According to the results given in table 6, the all indices for evaluating two-factorial model were found to have acceptable and goodness-of fit limits. It was observed that the values of $\chi^{2}(1.311 \mathrm{sd}), \chi^{2 / \mathrm{sd}}(1.311)$, RMSEA (0.046), NFI (0.94), GFI (0.93) and AGFI (0.89) were between acceptable fit limits while the values of NNFI (0.97) and CFI (0.99) were between goodness-of-fit limits (Hair, Anderson, Tatham \& Black, 1998; Jöreskog \& Sorbom, 1993). 


\section{Reliability}

After being applied exploratory and confirmatory factor analyses for short form of BIM, the Cronbach's alpha value of its factors and overall scale was calculated in order to determine reliability of the scale. The Cronbach's alpha value of behavior management factor was found to be.780; the Cronbach's alpha value of the instructional management factor was found to be .893 . The Cronbach's alpha value for the overall scale was found to be .784. Considering all these values, it can be said that the "Behavior and Instructional Management Scale" is highly reliable both in dimensions and in overall scale (Akgül \& Çevik, 2003).

\section{Discussion and Suggestions}

Effective learning environment and classroom management are very important for students' learning process (Gurcay, 2015), for it is expected that schools will ensure a neat and safe environment and the success of the students. This shows why classroom management is important for teachers (Rosas \& West, 2009). It is also important how teachers perform classroom management as effectively and efficiently as classroom management (Evertson \& Weinstein, 2006). For this reason, it is thought that it is beneficial to determine the beliefs of teacher and pre-service teachers about the management of behavior and instruction which are important parts of classroom management because, it can be said that competencies of teachers and pre-service teachers is as important as their beliefs. The scale of behavior and instructional management will benefit to determine beliefs of teachers and pre-service teachers in these areas and differentiation between their beliefs and abilities (Sass et al., 2016).

In this study, the validity and reliability studies of the Behavior and Instructional Management Scale and its adaptation into Turkish were conducted. As a result of the exploratory factor analysis, it was found 4factors structure with 18-item for the long form of BIM. However, the factors in this structure could not be named theoretically. In previous studies, it was stated that the 24-item long form of this scale should not be used in 
research because the expected theoretical structure could not be reached (Martin \& Sass, 2010; Sass et al., 2016). As a result of the exploratory analysis conducted for the 12-item short form of the scale, the expected theoretical structure was reached both in this study and in other studies (Martin \& Sass, 2010; Sass et al., 2016) and the obtained model was confirmed through and confirmatory factor analysis. It can be stated that Behavior and Instructional Management Scale is relatively short and the scale is appropriate for future research, which will possibly be conducted in Turkey according to reliability and validity results of this study. Moreover, this scale can be adapted into other languages and its factorial structure can be compared with the findings of this study.

\section{Acknowledgments}

A part of this study was presented an oral presentation at the 11th AGP International Humanities and Social Sciences Conference, 26-28 January 2018, Malta

\section{References}

Akbaba, S., \& Altun, A. (1998). Teachers' reflections on classroom management. Reports-Research (143). 1-13, ERIC 425148.

Akgul, A., \& Cevik, O. (2003). Istatiksel analiz teknikleri, SPSS'te işletme yönetimi uygulamaları. Ankara: Emek Ofset.

Bosch, K. (2006). Planning classroom management: a five-step process to creating a positive learning environment. Corwin Press.

Burden, P. (2017). Classroom management: Creating a successful K-12 learning community. John Wiley \& Sons.

Buyukozturk, Ş. (2013). Sosyal bilimler için veri analizi el kitabı. Pegem Akademi Yayıncılık.

Charles, C.M. (1991). Building classroom discipline. (4th ed), New York: Longman. 
Cokluk, Ö., Sekercioglu, G., \& Buyukozturk, S. (2012). Sosyal bilimler için çok değişkenli istatistik: SPSS ve LISREL uygulamaları. Ankara: Pegem Akademi.

Cum, S., \& Koc, N. (2013). Türkiye'de Psikoloji ve Eğitim Bilimleri Dergilerinde Yayımlanan Ölçek Geliştirme Ve Uyarlama Çalışmalarının İncelenmesi. Journal of Educational Sciences \& Practices, 12(24).

Doyle, W. (1986). Classroom organization and management.Handbook of research on teaching, 3, 392-431.

Edmonds, W. A., \& Kennedy, T. D. (2017). An applied reference guide to research designs: quantitative, qualitative, and mixed methods: Quantitative, qualitative, and mixed methods. Sage.

Emmer, E., Evertson, C., \& Worsham, M. E. (2006). Classroom management for middle and high school teachers (7th ed.). Boston: Pearson.

Emmer, E. T., Evertson, C., \& Worsham, M. E. (2000). Classroom management for secondary teachers. (5 th ed.). Boston: Allyn and Bacon

Evertson, C., \& Weinstein, C. S. (Eds.). (2006). Handbook of classroom management: Research, practice, and contemporary issues. Mahwah, NJ: Erlbaum.

Glickman, C. D., \& Tamashiro, R. T. (1980). Clarifying teachers' beliefs about discipline. Educational Leadership, 37(6), 459-464.

Gurcay, D. (2015). Preservice physics teachers' beliefs regarding their teacher efficacy and classroom management. Procedia-Social and Behavioral Sciences, 197, 1101-1106.

Gonzalez, L. E., Brown, M. S., \& Slate, J. R. (2008). Teachers who left the teaching profession: A qualitative understanding. Qualitative Report, 13(1), 1-11.

Hair, J. F., Anderson, R. E., Tatham, R. L. \& Black, W. (1998). Multivariate data analysis, Prentice-Hall. 
Hall, G. E., Quinn, L. F., \& Gollnick, D. M. (Eds.). (2017). The Handbook of Teaching and Learning. John Wiley \& Sons.

Hambleton, R.K. \& Patsula, L. (1999). Increasing the validity of adapted tests: Myths to be avoided and guidelines for improving test adaptation practices. Journal of Applied Testing Technology, 1(1), 1-30.

Henson, R. K., \& Roberts, J. K. (2001). A confirmatory factor analysis of preservice teachers' responses to the attitudes and beliefs on classroom control inventory. Paper presented at the annual meeting of the Southwest Educational Research Association, New Orleans. (ERIC Document Reproduction Service No. forthcoming)

Hutcheson, G. D., \& Sofroniou, N. (1999). The multivariate social scientist: Introductory statistics using generalized linear models. Sage.

Igbinoba, O. K., \& Marvelous, A. I. (2015). The impact of classroom management on students' academic performance in selected junior secondary schools in municipal area council, Abuja. International Journal of Education and Research, 3(9), 141-154.

Jalali, S., Panahzade, V., \& Firouzmand, A. (2014). Attitude towards computers and classroom management of language school teachers. International Journal of Instruction, 7(2), 35-50.

Joreskog, K. G., \& Sorbom, D. (1993). LISREL 8: Structural equation modeling with the SIMPLIS command language. Scientific Software International.

Kass, R. A., \& Tinsley, H. E. A. (1979). Factor analysis. Journal of Leisure Research, 11, 120-138

Laut, J. (1999). Classroom management: Beliefs pre-service teachers and classroom teachers concerning classroom management styles. Paper presented at the fall meeting of the Teachers' education conference, Charleston, SC. (ERIC Document Reproduction Service No. ED 445815).

Levin, J., \& Nolan, J. F. (1991). Principles of classroom management: A hierarchical approach. Prentice Hall. 
Martin, N. K., \& Baldwin, B. (1992). Beliefs regarding classroom management style: The differences between pre-service and experienced teachers. Paper presented at the annual meeting of the Mid-South Educational Research Association, Knoxville, TN (ERIC DocumentReproduction Service No. ED 355 213).

Martin, N. K., \& Sass, D. A. (2010). Construct validation of the behavior and instructional management scale. Teaching and Teacher Education, 26, 1124-1135.

Martin, N. K., Sass, D. A., \& Schmitt, T. A. (2012). Tests of measurement and structural invariance of a theoretical model predicting a teacher's intent-to-leave. Teaching and Teacher Education, 28, 546-559.

Martin, N., \& Shoho, A. (2000). Teacher experience, training, and age: The influence of teacher characteristics on classroom management style. Paper presented at the annual meeting of the Southwest Educational Research Association, Dallas, TX. (ERIC Document Reproduction Service No. ED 440963)

Martin, N. K., Yin, Z., \& Baldwin, B. (1998). Construct validation of the attitudes and beliefs on classroom control inventory. Journal of Classroom Interaction, 33(2), 6-15.

Martin, N., Yin, Z., \& Baldwin, B. (1997). Beliefs regarding classroom management style: Differences between male and female, urban and rural secondary level teachers. Paper presented at the annual meeting of the American Educational Research Association, Chicago, IL. (ERIC Document Reproduction Service No. ED 408136).

Martin, N. K., Yin, Z., \& Mayall, H. (2007). The attitudes and beliefs on classroom control inventory revised and revisited: A continuation of construct validation. Journal of Classroom Interaction, 42(2), 11-20.

Martin, N., Yin, Z., \& Mayall, H. (2006). Classroom management training, teaching experience and gender: Do these variables impact teachers' attitudes and beliefs toward classroom management style? Paper presented at the annual conference of the Southwest Educational Research Association. Austin, TX. 
Marzano, R. J., Gaddy, B. B., Foseid, M. C., Foseid, M. P., \& Marzano, J. S. (2005). A handbook for classroom management that works. Alexandria, VA: Association for Supervision and Curriculum Development.

Marzano, R. J., Marzano, J. S. \& Pickering, D. J. (2003). Classroom management that works: Research-based strategies for every teacher. Alexandria, VA: Association for Supervision and Curriculum Development.

Ming-tok, H. \&Wai-shing, L. (2008). Classroom Management Creating A Positive Learning Environment. Hong Kong: Hong Kong University Press,

Onwuegbuzie, A. J., Witcher, A. E., Filer, J., \& Downing, J. (2000). Factors associated with teachers' beliefs on discipline. Paper presented at the Annual Meeting of the MidSouth Educational Research Association, Lexington, $\mathrm{KY}$

Rosas, C., \& West, M. (2009). Teachers Beliefs about Classroom Management: Pre-service and Inservice Teachers' Beliefs about Classroom Management. International Journal of Applied Educational Studies, 5(1), 54-61.

Rust, F. O. (1992). The first year of teaching: It's not what they expected. Paper presented at the annual conference of the American Educational Research Association: San Francisco, CA.

Sass, D. A. (2011). Testing measurement invariance and comparing latent factor means within a confirmatory factor analysis framework. Journal of Psychoeducational Assessment, 29(4), 347-363.

Sass, D. A., Lopes, J., Oliveira, C., \& Martin, N. K. (2016). An evaluation of the Behavior and Instructional Management Scale's psychometric properties using Portuguese teachers. Teaching and Teacher Education, 55, 279-290.

Savran, A. (2002). Preservice science teachers' efficacy beliefs regarding science teaching and their classroom management beliefs. (Unpublished Master's thesis). Middle East Technical University, Ankara. 
Secer, I. (2015). SPSS ve LISREL ile pratik veri analizi: Analiz ve raporlaştırma. Anı Yayıncılık.

Shepherd, T. L., \& Linn, D. (2015). Behavior and Classroom Management in the Multicultural Classroom. Sage.

Tauber, R. T. (2007). Classroom management: Sound theory and effective practice. Greenwood Publishing Group.

Unal, Z., \& Unal, A. (2012). The impact of years of teaching experience on the classroom management approaches of elementary school teachers. International Journal of Instruction, 5(2), 41-60.

Willower, D. J., Eidell, T. L., \& Hoy, W. K. (1967). The school and pupil control ideology (24). Pennsylvania State University.

Wolfgang, C. H., \& Glickman, C. D. (1980). Solving discipline problems: Strategies for classroom teachers. Allyn and Bacon, Inc., Longwood Division, College and Professional Publications, 470 Atlantic Avenue, Boston, MA 02210.

Williams, K. C. (2009). Elementary classroom management: A studentcentered approacht o leading and learning. Sage Publications.

Wolfgang, C. H., \& Glickman, C. D. (1980). Solving Discipline Problems: Strategies for Classroom Teachers. Allyn and Bacon, Inc., Longwood Division, College and Professional Publications, 470 Atlantic Avenue, Boston, MA 02210.

Wolfgang, C. H., \& Wolfgang, M. E. (1995). The three faces of discipline for early childhood: empowering teachers and students. Allyn and Bacon, 160 Gould Street, NeedhamHeights, MA 02194-2310. 


\begin{abstract}
Ali Sabanci is a Professor Doctor at the Department of Educational Sciences, Educational Administration, Supervision, Planning and Economy at Akdeniz University, Turkey. Some of his research interests include educational leadership, supervision of educational institutions, classroom management professional ethics, stress, job satisfaction and organizational commitment

Contact Address: Akdeniz University, Faculty of Educational Sciences, Konyaaltı\ANTALYA, TURKEY

E-mail: alisabanci@akdeniz.edu.tr

Gülnar Özyildirim is Research Assistant Doctor of the Department of Educational Sciences at Akdeniz University, Turkey. She received her Ph.D in Educational Administration and Supervision. Her research interests include classroom management, professional ethics and educational supervision

Contact Address: Akdeniz Universtity, Faculty of Education, AntalyalTURKEY

E-mail: gulnarozyildirim@gmail.com
\end{abstract}

